\title{
Pollution Resistance Assessment of Plants Around Chromite Mine Based on Anticipated Performance Index, Dust Capturing Capacity and Metal Accumulation Index
}

\author{
Kalicharan Mandal \\ Council of Scientific and Industrial Research Institute of Minerals and Materials Technology \\ Nabin Kumar Dhal ( $\square$ nkdhal@immt.res.in ) \\ Council of Scientific and Industrial Research Institute of Minerals and Materials Technology
}

\section{Research Article}

Keywords: Bio-monitor, Anticipated performance index, Dust capturing capacity, Metal accumulation index, Chromite mine, Greenbelt development

Posted Date: June 28th, 2021

DOI: https://doi.org/10.21203/rs.3.rs-623200/v1

License: @ (1) This work is licensed under a Creative Commons Attribution 4.0 International License. Read Full License

Version of Record: A version of this preprint was published at Environmental Science and Pollution Research on April 22nd, 2022. See the published version at https://doi.org/10.1007/s11356-022-20246-6. 


\section{Abstract}

Plant species sustaining under a polluted environment for long time are considered as potentially resistant species. Those plant species can be considered as an eco-sustainable tool used to bio-monitor and mitigate pollution. This study was carried out on total ten commonly available plant species to assess their anticipated performance index (API), Dust capturing capacity (DCC) and Metal accumulation index (MAl) in chromite mine and control area. According to Anticipated performance index (API) Macranga peltata, Holarrhena pubescens and Ficus hispida are highly tolerant species while Terminalia arjuna and Trema orientalis are intermediate tolerant species. Ficus hispida was also showed the highest dust capturing capacity $\left(5.94 \pm 0.43 \mathrm{mg} / \mathrm{cm}^{2}\right)$ and whereas Woodfordia fruticosa $\left(1.03 \pm 0.11 \mathrm{mg} / \mathrm{cm}^{2}\right)$ was found to be lowest. Metal accumulation index ranged from 17.29 to 4.5 and 6.38 to 1.94 at mine and control area respectively. Two-way ANOVA analysis revealed area wise significant differences between biochemical and physiological parameters. Also, result showed that the pollution level and heavy metal affected different biochemical and physiological parameter of plant species at mining area. The plant species with highest API, DCC and MAI value could be recommended for greenbelt development in different polluted area.

\section{Introduction}

The economic growth and development of a nation is dependent on its mining sector to a great extent which is associated with the exploitation of the mineral resources (Lebre et al., 2017). Whereas mining plays a significant role in economic growth at the same time it's adversely impact on environment. Worldwide mining activity is one of the serious contributors to the environmental pollution and considered one of the significant sources of air, soil and water pollution (Oluwoye et al., 2017; Golui et al., 2019; Sahu and Basti, 2020). From the open cast mining, a massive amount of gaseous pollutant, toxic substance, fine ore particles and dust releases to the environment (Das et al. 2020). These releases pollutants mix with atmosphere and transported long distance through air from mine area and leads to pollution in the surrounding undisturbed area (Ni et al., 2018; Khazini et al., 2021)

Green vegetation around the mining area can act as an eco-friendly and cost-effective tool to reduce pollution. In polluted environment, green plant play a crucial function in improving environmental quality by accumulating toxic pollutant (Gheorghe and lon 2011; Kaur and Nagpal, 2017). They have a great potential to absorption, adsorption and accumulation of pollutants from both soil and air (Manara, 2012; Remon et al., 2013). They transport toxic substances from soil and air to biotic environment. Green plants perform as pollution sink as they provides broad surface area for absorb and accumulation of pollutants hence, plantation of highly tolerant plant species can help in effective green belt development to clean up polluted areas, further improving the environmental quality (Remon et al., 2013; Selmi et al., 2016; Karmakar \& Padhy, 2019;). Selection of suitable plant for greenbelt development differ from region to region.

Air pollution tolerance index (APTI) and anticipated performance index (API) are considered best and reliable indices to select appropriate tolerant and sensitive plant species. The highly tolerant plant species are chosen to perform against the environmental pollution and the sensitive species might be use for bioindicator (Rai, 2016; Javanmard et al. 2020; Roy et al. 2020; Molnár, 2020). Four biochemical parameters such as Total chlorophyll content (TCC), Leaf extract pH (pH), Ascorbic acid (AA) and Relative water content (RWC) were used to develop the APTI (Singh and Rao, 1991). API is an upgradation of APTI, which is more appropriate indices for selection of tolerant and sensitive species in a particular region. API is developed with the combination of APTI value of each individual species along with some morphological (Plant habit, canopy structure, types of plant, laminar structure) and socioeconomic characters (Mondal et al., 2011). Dust, particulate matter and heavy metal are the most prevalent and rapidly effecting environment causing critical problems to living organism (Xiu et al., 2020; Kong et al., 2021). Plants are the best efficient at accumulate and capture to heavy metal and dust particle. In order to combat such pollutant, Dust capturing capacity (DCC) and Metal accumulation index (MAI) are also considered to select the suitable plant species.

Sukinda chromite mine area is one of the most populated area in the world, having numbers of open cast chromite mine. This mining area holds 183 million tons of raw chromite reserves, which is total $97 \%$ of total reserves of the country and approximately 3.8 million tons of chromite produces per year (IBM 2010). Due to various mining activity a massive amount of ore particles and dust produced and get blown away through air to surroundings areas, subsequently causes chromium (Cr) contamination by the atmospheric deposition (Das et al., 2020). According to report of Blacksmith Institute (2007), extensive pollution of the area due to excessive chromite ore mining has made it fourth most polluted place in the world.

Through this study, we provide an integrated approach to the selection of both pollution tolerant and sensitive plant species. To know physiological and biochemical tolerance level of plants we studied air pollution tolerance index (APTI) and anticipated performance index (API). Heavy metal accumulation and dust capturing capacities of total ten plants were also examined. This study is confined only on commonly found native plant species in this area. So, our study will contribute convenient knowledge/ information for the establishment of greenbelt in this mining area as well as different other polluted areas to improve the soil and air pollution. 


\section{Materials And Methods}

\subsection{Study area}

Present study work was done at two areas namely Sukinda chromite mine valley and Tomka forest, located in Jajpur district, Odisha, India. Sukinda Chromite mine valley is the largest chromite producer in India, almost $99 \%$ of country's chromium are produce from this valley. Stretching between $21^{\circ} 00^{\prime} \mathrm{N}$ to $21^{\circ} 05^{\prime} \mathrm{N}$ latitude and $85^{\circ} 44^{\prime} \mathrm{E}$ to $85^{\circ} 53^{\prime} \mathrm{E}$, occupies an area of two hundred square kilometre holds an estimated 183 million tons of raw chromium deposits (Nayak and Kale 2020) and consists of an extensive plateau in the interior with a foreground of wide coastal plain and underlain by Precambrian rock. Currently, 20 open cast and 2 underground mines are functional in the valley producing 160 million tons of overburden. It also releases 11.73 tons of hexavalent chromium $(\mathrm{Cr}(\mathrm{VI}))$ to the environment every year, making it the fourth-worst polluted places in the world. (Dhal et al. 2011; Das et al. 2020). Tomka forest considered as control area due to pollution free atmosphere, located about $40 \mathrm{~km}$ away from the mining area.

\subsection{Plant species sampling}

In total, leaf samples of ten plant species namely: Ailanthus excels, Bixa orellana, Ficus hispida, Macranga peltata, Woodfordia fruticose, Trema orientalis, Terminalia arjuna, Holarrhena pubescens, Calicarpa tomentosa and Combretum roxburghii plant species were collected during winter session 2020. These plant species were considered on the basis of abundance and their socioeconomic importance. Three replicate of healthy, mature and fully developed plant leaves sample were collected for each species. The replicate plant species were chosen as those individual species having similar height and breast diameter. After being sampled leaves were placed into zipper locked bags and kept in a portable ice-box, then transferred to the laboratory. Leaves were collected and transferred very carefully form plant to zipper locked bag, for ensuring least disturbance to their surface dust. For further biochemical analysis leaves were washed with tap water followed by distil water, and stored in $-20^{\circ} \mathrm{C}$.

\subsection{Analysis of the biochemical parameters of the plants}

\subsubsection{Relative water content $(R)$}

After taking the fresh weight (FW), leaf were submerged in deionized water for 24 hours. Then turgid weight (TW) recorded by soak up the surface water of leaf. Overnight dried leaf in oven at $80^{\circ} \mathrm{C}$ used for taking dry weight (DW) (Liu and Ding, 2008).

RWC $(\%)=[(F W-D W) /(T W-D W)] \times 100$

\subsubsection{Total chlorophyll content ( $T$ )}

Total chlorophyll content of leaves were calculated following the procedure mention by Arnon (1949). $1 \mathrm{~g}$ of fresh leaves were crushed by using $10 \mathrm{ml}$ of $80 \%$ acetone and centrifuged at $5000 \mathrm{rpm}$ for $5 \mathrm{~min}$. After collection of supernatant volume were made up to $30 \mathrm{ml}$ by $80 \%$ acetone and absorbance was taken at 645 and $663 \mathrm{~nm}$ by using spectrophotometer (Analytical UV-Vis 3090V). Calculation of total chlorophyll content was estimate by following formula

$T\left(\frac{m g}{g}\right)=\frac{(20.2 * A 645+8.02 * A 663) * V]}{1000 * W(g)}$

Where, $A 645=$ Absorbance at $645 \mathrm{~nm}, \mathrm{~A} 663=$ Absorbance at $663 \mathrm{~nm}, \mathrm{~V}=$ Total volume of extract $(\mathrm{ml}), \mathrm{W}=$ Weight of leaf in gram.

\subsubsection{Ascorbic acid (A)}

Ascorbic acid estimation was done by using modified colorimetric 2,6-dichlorophenol indophenol technique. $0.5 \mathrm{~g}$ of fresh leaves was extracted in $4 \%$ oxalic acid and made up to $30 \mathrm{ml}$ volume and centrifuged at $6000 \mathrm{rpm}$ for $10 \mathrm{~min} .10 \mathrm{ml}$ of $4 \%$ oxalic acid added with $5 \mathrm{ml}$ of the supernatant and titrate against the dye. Titration was done till pink colour appeared which presence for a few second.

$$
A\left(\frac{m g}{g}\right)=\frac{0.5(m g) * V 2(m l) * 30(m l)}{V 1(m l) * 5(m l) * \text { weight of sample }(\mathrm{g})}
$$

Where,

V1 = Volume of dye titrated against the working standard

V2 = Volume of dye titrated against the sample

\subsubsection{Leaves Extract pH (P)}


The $\mathrm{pH}$ of the leaves were determined with the help of $\mathrm{pH}$ meter by crushed $1 \mathrm{~g}$ of fresh leaves and homogenizing in $40 \mathrm{~mL}$ of deionized water.

\subsubsection{Air Pollution Tolerance Index (APTI)}

APTI was calculated following the equation described by Sing and Rao (1991).

$\mathrm{APTI}=[\mathrm{A}(\mathrm{T}+\mathrm{P})+\mathrm{R}] / 10$

Where $\mathrm{A}=$ Ascorbic acid $(\mathrm{mg} / \mathrm{g}), \mathrm{T}=$ Total chlorophyll content $(\mathrm{mg} / \mathrm{g}), \mathrm{P}=\mathrm{pH}$ of leaf extract, $\mathrm{R}=$ Relative water content $(\%)$.

\subsubsection{Anticipated Performance Index (API)}

Combining some morphological and socio-economic characteristics (plant habit, type of plant, laminar characters, canopy type, and economic value) with APTI value, API is estimated. The API score is calculated according to the following formula

$\operatorname{API}(\%)=($ Total positives $) \times 100] / 10$

The maximum positive is allotted for a plant species is 16 . According to API score plant species were categorise into eight different group (e.g., not recommended, very poor, poor, moderate, good, very good, excellent and best).

\subsection{Dust Capturing Capacity (DCC)}

Dust capturing capacity was quantified with the help of Petri dish. A petri dish was oven dried and weighed the initial weight (W1). Upper and lower surface dust of a leaf washed with deionized water and transferred to the petri dish. Then petri dish was completely dried and weighed to record final weight (W2). Surface area (A) of the leaf measured with the help of graph paper. Dust capturing capacity was calculated by the following formula

$\mathrm{W}=\mathrm{W} 2-\mathrm{W} 1 / \mathrm{A}$

\subsection{Analysis of metal concentration in leaves}

The washed leaves were completely dried at $60^{\circ} \mathrm{C}$ in hot air oven. $1 \mathrm{~g}$ leaves material were digested using 2 acid i.e. HCLO4 and HNO3 in the ratio of 1:2 (Samecka-Cymerman and Kempers 1999). Digested solutions were diluted with double distil water and final volume make up to $50 \mathrm{ml}$. Then digested solutions were analysed for Al, Cr, Fe, Ni, Pb and Zn by PerkinElmer ICP-OES (Model: Optima 2100 DV).

\subsection{Metal Accumulation Index (MAl)}

Metal accumulation capability of plant species are calculated by the using metal accumulation index (MAl) formula (Hu et al., 2014).

$M A I=\left(\frac{1}{N}\right) \sum_{J=1}^{n} I J$

Where, $\mathrm{N}=$ Number of metals, $\mathrm{IJ}=$ is sub-index of $\mathrm{J}$ gained by dividing the metal concentration by its standard deviation. It is depend on collected sample number.

\section{Results And Discussions \\ 3.1. Ascorbic acid (A)}

Ascorbic acid or vitamin $\mathrm{C}$ is an important low molecular weight non-enzymatic antioxidant present in plant chloroplasts. This antioxidant plays a crucial function in light reaction of photosynthesis, regulate various metabolic biosynthesis pathway and it also protect plant from biotic and abiotic stress (Singh and Verma, 2007). Throughout photosynthetic electron transfer, ascorbic acid react and scavenge reactive oxygen species (ROS). Therefore biosynthesis and concentration of this antioxidant directly proportionate to tolerance level of plant (Smrinoff and Wheeler, 2000; Wang et al., 2018). In mining area highest ascorbic acid content (mg/g in fresh leaves) was found in $H$. pubescence $(26.83 \pm 1.01)$ followed by M. peltata $(24.66 \pm 0.99)$, T. orientalis $(22.81 \pm 0.8)$, F. hispida (19.63 \pm 2.77$)$, and lowest content was noticed in $C$. roxburghii $(8.76 \pm 0.95)$, followed by $C$. tomentosa $(9.46 \pm 1.93)$ and $W$. fruticosa $(9.86 \pm 1.22)$. In comparison to the control area considerable difference was found in ascorbic acid contents in all plant species (Figure: 1$)$. In control area highest amount found in $M$. peltata $(14.28 \pm 0.93)$ followed by $T$. arjuna $(12.85 \pm 0.57)$ and $H$. pubescence $(11.36 \pm 2.22)$ and lowest amount found in $C$. tomentosa $(4.11$ $\pm 0.7)$ followed by $C$. roxburghii $(4.72 \pm 1.03)$ and $A$. excels $(5.56 \pm 0.91)$. 
Ascorbic acid react with various ROS (i.e. superoxide radical, singlet oxygen and hydroxyl radical) and protects pigments and nucleic acid. Elevated amount of ascorbic acid increases the tolerance level of plant under pollution environment as well as others stress condition (like, drought, salt, temperature etc.) (Wang et al., 2018). Hence, plants synthesized higher level ascorbic acid in polluted environment are evaluated as tolerant species. In our study, ascorbic acid content is higher at mining area and lower at control area for all examined plant species. The enhancement of ascorbic acid in all species from mining area might be due to elevated production of ROS, through accumulation of toxic metal in plant body.

\subsection{Relative Water Content (R)}

Relative water content signify the balance between plant water uptake and release. Water content maintain turgor pressure and cell wall permeability in plant body. During pollution condition different pollutant enhance cell permeability, which leads to deficiency of water and nutrients, derive to prior senescence of leaves and bark (Achakzai et al., 2017; Safari et al, 2019). So, relative water content of plants is a suitable physiological parameter to measure water condition in plant body. All the species had more relative water content in control area than mining area (Figure: 1). Highest relative water content in mining area was found in M. peltata (93.71 \pm 2.69$)$ and lowest in $A$. excels $(64.81 \pm 7.76)$. In control area, the relative water content of leaf of the plant species differed from maximum of $98.22 \pm 0.33$ in $F$. hispida to a minimum of $69.31 \pm 1.37$ in $A$. excelsa (Table).

The relative water content of plant leaves in mining area is decreased might be due to high pollutants and heavy metal contamination, it also specify unbalanced physiological condition of the plant. Heavy metal contamination in plant body reduce the water transport from root to leaves (Bercelo and Poschenrieder, 1990). Under any stress condition high water content help to sustain physiological and biochemical balance in a plant body. Higher level of relative water content in plants increases the tolerance strength of plant towards pollution stress (Gupta et al., 2016; Karmakar and Padhy, 2019).

\subsection{Total chlorophyll content (T)}

The photosynthetic pigment chlorophyll, found in the chloroplasts of green plants, is an index of productivity and is called a photoreceptor. Chlorophyll plays an important role in plant photosynthesis, so measurement of total chlorophyll content is a significant measure to assess the effect of pollution on the plant. The decreased level of total chlorophyll content of all species were noticed in the mining area as compared to the control area (Figure: 1). At mining area highest chlorophyll content (mg/g of fresh weight) was found in $H$. pubescence $(1.81 \pm 0.01)$ followed by $T$. orientalis $(1.3 \pm 0.11)$ and $M$. peltata $(1.12 \pm 0.05)$. Lowest found in $B$. Orellana (0.44 \pm 0.01$)$ followed by $W$. fruticosa $(0.58 \pm 0.007)$ and $C$. roxburghii $(0.61 \pm 0.009)$. At control area highest found in $H$. pubescence $(2.33 \pm 0.22)$ followed by $M$. peltata $(1.43 \pm 0.24)$ and $T$. orientalis (1.39 \pm 0.19$)$. Lowest found in B. Orellana $(0.75 \pm 0.09)$ followed by F. hispida $(0.9 \pm 0.07)$ and $A$. excels $(1.06 \pm$ 0.13). Chlorophyll have a highly organized state that may go through various photochemical reaction like oxidation, reduction and reversible bleaching in different pollutant condition (Karmakar et al., 2021). Decreased level of chlorophyll at mining area might be due to dust deposition on leaves surface and heavy metal accumulation. Dust deposition on leaves surface inhibit the sunlight absorption and blocks the stomatal pore, thus decreased the rate of photosynthesis which is important for chlorophyll synthesis (Roy et al., 2020). After accumulation of heavy metal, $\mathrm{Mg}^{++}$ion of chlorophyll replace by the another metal ion and breakdown into phaeophytin (Karakoti et al, 2014). High pollution stress reduces the total chlorophyll content at the polluted site. But those species are able to maintain a high level of chlorophyll known as tolerant species.

\subsection{Leaves Extract pH (P)}

Leaves extract $\mathrm{pH}$ is a biochemical parameter of plant that signify as an indication of stress. The pH of the leaf extracts ranges from $6.8 \pm$ 0.13 to $5.1 \pm 0.06$ and $7.17 \pm 0.14$ to $5.53 \pm 0.12$, at polluted and control area respectively, with $F$. hispida and $B$. orellana having highest and lowest value. The $\mathrm{pH}$ of plants has shown a good relationship with the susceptibility to pollution. Low pH reduced the photosynthetic activity by altering the stomatal activity while a higher level of $\mathrm{pH}$ in plants can increase tolerance toward pollution by enhancing the synthesis rate of ascorbic acid from hexose sugar (Escobedo et al., 2008). The presence of acidic pollutant in the environment increases the acidic nature of the leaf by decreasing $\mathrm{pH}$. Hence, those plant species have higher leaf extract $\mathrm{pH}$ are considered as pollution tolerant species. It is evidenced that all the plant species collected from mining area showed an acidic $\mathrm{pH}$. Leaves $\mathrm{pH}$ decline in mining areas may be due to the existence of heavy metal in the environment. Karmakar \& Padhy (2019) and Nadgorska-Sochaet al. (2017) has been reported that leaves pH influences in the presence of heavy metal like $\mathrm{Cd}, \mathrm{Cr}$, Ni, and $\mathrm{Zn}$.

\subsection{Air pollution tolerance index (APTI)}

The APTI is an established method for evaluation of plants with regarding to their sensitivity to pollutants. Depending on APTI value plants species are categories into four different group i.e. $\leq 15=$ sensitive, 15-19= Intermediate, $20-24=$ moderately tolerant and $>24=$ tolerant (Singh et al., 1991). APTI values of each plant species were calculated using the mean values of T, P, R and A values, so the standard deviation of APTI values are not mentioned (Table: 1). At mining area shown that APTI value range from 30.24 to 12.48 . Highest value was

Page 5/15 
recorded in $H$. pubescence (30.24) followed by M. peltata (25.96), T. orientalis (25.62) and F. hispida (22.52). According to APTI range $H$. pubescence, M. peltata and T. orientalis are tolerant species as their APTI value $\geq 24$. F. hispida (22.52) is only moderately tolerant species. $C$. roxburghii (18.71), and T. arjuna (16.51) are the intermediate species. Whereas, $A$. excelsa, $B$. Orellana, and $C$. tomentosa are sensitive species $(\mathrm{APTI} \leq 15)$. At control area the APTI showed a decline (Figure: 1 ) value ranging from 21.51 to 11.41 , with $M$. peltata and $C$. roxburghii having highest and lowest value respectively. All species are grouped into three category i.e. sensitive, intermediate, moderately tolerant, no species could qualify as tolerant at control areas. A strong correlation between ascorbic acid and APTI at both mining $\left(R^{2}=0.86\right)$, and control area $\left(\mathrm{R}^{2}=0.83\right)$ was noticed. Whereas remaining three parameters $(\mathrm{pH}$, total chlorophyll, and relative water content) have insignificant low correlation with APTI. This indicates that, as the pollution level increases ascorbic acid in plants also increases to combat the pollution stress. Some previous study also have found similar kind of correlation between ascorbic acid and APTI value (Rai \& Panda 2014, Bharti et al. 2018; Roy et al. 2020). Depending on the pollution condition, same species can act differently such as, tolerant, intermediate or sensitive. Plantation of tolerant plant species, to mitigate environmental pollution is a sustainable prospective to meet industrial and commercial growth.

\subsection{Anticipated Performance Index (API)}

Different species act differently to different pollution stress. Therefore grouping of species on the basis APTI value is only useful to evaluate tolerance status of plant. Hence, only APTI value is not enough for the selection of appropriate tolerant species to develop greenbelt in polluted area. By incorporate APTI value with economic value and morphological characters likes, plant habit, canopy structure, laminar character and plant types the API grade of different species are calculated. In the mining area M. peltata scored highest API value followed by $H$. pubescens and $F$. hispida qualified excellent, very good and good species respectively for greenbelt development (Table: 2). Among the rest of species two were ( $T$. arjuna and T. orientalis) qualified as a moderate. C. tomentosa, C. roxburghii, A. excels, Bixa orellana and W. fruticosa are poor, very poor and not recommended for greenbelt development, because of their low API value (50 - 25). In control areas also similar result was found, $M$. peltata scored highest API value followed by $H$. pubescens and $F$. hispida. But all three species qualified as a good species for greenbelt development. Among the rest of the plant species, $T$. arjuna is moderate, $C$. tomentosa is poor, three species $(A$. excelsa, $B$. orellana, and $C$. roxburghii) are very poor and $W$. fruticosa is not recommended for greenbelt development. Screening all the species by using only APTI value H. pubescence, M. peltata and T. orientalis has been assessed as tolerant species and F. hispida was moderately tolerant species. But after combine APTI value with morphological and economic value, then $F$. hispida qualified as a tolerant species along with $H$. pubescence and M. peltata and T. orientalies qualified as a moderate along with $T$. arjuna.

\subsection{Dust capturing capacity (DCC)}

Variation of dust capturing capacity of collected species at mining and control areas were depicted in (Table: 3). F. hispida was found the highest dust capturing capacity $\left(5.94 \mathrm{mg} / \mathrm{cm}^{2}\right)$ in mining area followed by $C$. tomentosa $\left(4.26 \mathrm{mg} / \mathrm{cm}^{2}\right), \mathrm{H} . \mathrm{pubescence}\left(3.6 \mathrm{mg} / \mathrm{cm}^{2}\right), \mathrm{M}$. peltata $\left(3.51 \mathrm{mg} / \mathrm{cm}^{2}\right)$ and T. orientalis $\left(3.5 \mathrm{mg} / \mathrm{cm}^{2}\right)$. Remaining species (A. excels, B. orellana, C. roxburghii, T. arjuna, W. fruticosa) showed the lower dust capturing capacities in mining area. In control areas $M$. peltata $\left(0.39 \mathrm{mg} / \mathrm{cm}^{2}\right)$ showed highest dust capturing capacities followed by $C$. tomentosa $\left(0.37 \mathrm{mg} / \mathrm{cm}^{2}\right)$ and . hispida $\left(0.36 \mathrm{mg} / \mathrm{cm}^{2}\right)$ and lowest dust capturing capacities showed by $W$. fruticosa $(0.14$ $\left.\mathrm{mg} / \mathrm{cm}^{2}\right)$ followed by $C$. roxburghii $\left(0.16 \mathrm{mg} / \mathrm{cm}^{2}\right)$ and $B$. orellana $\left(0.17 \mathrm{mg} / \mathrm{cm}^{2}\right)$. Dust capturing capacity of plant significantly depend on species to species. Several micro-characters, macro-characters and surrounding environment affect the plant's dust capturing capacity. Micro-characters such as stomatal size and density, presence of trichome, pubescence, wax layer, and macro-characters like height of plant, canopy structure, leaves arrangement on stem, petiole area significantly influence the dust capturing capacity of plant species (Mo et al., 2015; Leonard et al., 2016) F. hispida, C. tomentosa, H. pubescence, M. peltata and T. orientalis contribute high level of dust capturing capacities due to presence of tricome in both side of leaves surface. Similar findings were supported some recent studies by Roy et al. (2020) and Chaudhary et al. (2019) found higher dust capturing capacities in genus Ficus . Roy et al. (2020) also found that Ailanthus excelsa had lowest value due to its small and glabrous leaf petiole. According to single factor ANOVA showed significant differences in dust capturing capacities in both areas $\left(F=24.11, F_{\text {critical }}=4.41\right)$, at 0.05 significance level. Area wise differences may be due to high atmospheric pollution and anthropogenic activity.

\subsection{Assessment of heavy metal within the leaf}

Heavy metals accumulation in plants can be from both, adsorption through stomata from areal dust deposition and root uptake from soil. So, it impossible to distinguish whether the accumulated heavy metal came from the soil or from the air (Serbula et al. 2012; Norouzi et al. 2015). In mining areas analysed plant leaves revelled that they were surpass the permissible limit of WHO (1996) standards. Al, Cr and Fe content were extremely higher within the all investigated plants leaves. Average metals accumulation ranges of all investigated plants at both the area are represented in (Table: 4). Fe concentration found higher in all plant leaves of mining area ranging from $1028.87 \pm 5569$ to $6793.93 \pm$ $797.15 \mathrm{mg} / \mathrm{kg}$ and in the control area ranged between $245.89 \pm 36.76$ to $57.04 \pm 15.18$. Highest Fe accumulation found in $F$. hispida leaves in mining area $(6793.93 \pm 797.15 \mathrm{mg} / \mathrm{kg})$ and in $C$. tomentosa leaves in control area $(245.89 \pm 36.76 \mathrm{mg} / \mathrm{kg})$. Al accumulation ranged between

Page 6/15 
$159.43 \pm$ to $1358.70 \pm \mathrm{mg} / \mathrm{kg}$ at the mining area. The highest Al accumulation was detected in F. hispida followed by M. peltata (833.07 \pm $\mathrm{mg} / \mathrm{kg})$ and lowest was detected in $W$. fruticose followed by $T$. orientalis $(183.20 \pm \mathrm{mg} / \mathrm{kg})$. Compared with control area highest accumulation found in F. hispida $(5.23 \pm \mathrm{mg} / \mathrm{kg})$ and lowest was found in $T$. orentalis $(0.62 \pm \mathrm{mg} / \mathrm{kg})$. The highest content of Cr accumulation were found in F. hispida ( $432.27 \pm \mathrm{mg} / \mathrm{kg}$ ) followed by M. peltata (328.03 $\pm \mathrm{mg} / \mathrm{kg}$ ) and lowest accumulation were found in $C$. tomentosa (48.97 $\pm \mathrm{mg} / \mathrm{kg})$ followed by $B$. orelana $(52.83 \pm \mathrm{mg} / \mathrm{kg})$. Maximum accumulation of Ni were found in C. roxburghii $(64.57 \pm \mathrm{mg} / \mathrm{kg}) \mathrm{followed} \mathrm{by} M$. peltata $(62.57 \pm \mathrm{mg} / \mathrm{kg})$.

\subsection{Metal Accumulation Index (MAl)}

MAl is used to evaluate the heavy metals accumulation capacities in plants using standard formula (Hu et al., 2014; Karmakar \& Padhy, 2019). The MAl value of analysed plant species are given in the (Table: 4). At mining area MAl ranged from 4.5 (W. fruticosa) to 17.29 ( $C$. tomentosa). The trend followed was C. tomentosa $(17.29)>$ F. hispida $(10.31)>$ M. peltata $(10.16)>H$. pubescens $(9.74)>A$. excelsa $(7.46)>$ T. arjuna (7.05) $>$ T orientalis (6.89) $>$ B. orellana (5.17) $>W$. fruticosa (4.5). At control area the trend followed was $F$. hispida (6.38) $>C$. roxburghii (3.4) > T. arjuna $(3.17)>M$. peltata $(3.15)>C$. tomentosa $(2.88)>$ A. excelsa $(2.82)>W$. fruticose $(2.57)>H$. pubescens $(2.34)>T$. orientalis (2.26) $>$ B. orellana (1.94). In both area $F$. hispida had higher MAl value (mining area $=10.31$, control area $=6.38$ ), indicating that it has higher metal accumulation capacity. However, MAl of $A$. excelsa (7.46) in Sukinda chromite mine area is higher than previously reported by Roy et al. (2020) in industrial area (2.13) and commercial area (2.03). In another study at China similar kind of result was found by Hu et al. (2014). MAI value of Sophora japonica in Beijing (9.0) was higher than reported in Yan'an city (2.56). This fluctuation of MAI value may mainly depending on local atmospheric chemistry and geology. It also depend on the other factors, such as amount of metal deposited on leaf surface, sampling height, time and plant characteristics as well as the capacity of removal air pollutant and accumulation of metal (Castanheiro et al., 2020; Jia et al., 2021). Plant species with higher MAl values have a better metal accumulation capacity and considered metal tolerant species, those species can use impediment between contaminated and uncontaminated area. Those plant species that have lower MAI value are considered sensitive to metal and can be used as bioindicators of metal pollution.

\section{Conclusion}

Based on dust capturing capacities and metal accumulation index as well as APTI and API indices F. hispida, M. peltata and H. pubescens can be use as tolerant species and could be recommended for greenbelt development to mitigate pollution. Those plant species $(A$. excelsa, B. orellana, $C$. roxburghii, $W$. fruticosa, $T$. arjuna, T. orientalis) have lower APTI and API value could be used as sensitive species for biomonitoring of environmental pollution. Our study also finds that $C$. tomentosa is the highest metal accumulation capacities, but according to anticipated performance index it is a poor performer toward pollution. So, these species could be used as hyper-accumulator to mitigate heavy metal contamination from air and soil. The physiological and biochemical response of plant varies on species to species and also area to area. But, more biochemical and physiological research is needed to confirm the effect and response of plant species in a particular pollution stress condition.

\section{Declarations}

\section{Acknowledgements}

The authors are thankful to Director of CSIR-IMMT, Bhubaneswar, Odisha, India for providing laboratory facility for the work. Mr K Mandal also thankful to the University Grand Commission (UGC), India for providing fellowship as a Ph.D. scholar.

Ethics approval and consent to participate: Not applicable

Consent for publication: Not applicable

Availability of data and materials: All data generated or analysed during this study are included in this published article.

Competing interests: The authors declare that they have no competing interests.

Funding: Not applicable

\section{Authors' contributions:}

1. Nabin Kumar Dhal: (Corresponding author)

ontribution: Conceptualization of the work, supervision, preparing the manuscript.

2. kalicharan Mandal: (First author) 
Contribution: Methodology, sample collection, data analysis and interpretation, preparing the manuscript.

\section{References}

1. Achakzai K, Khalid S, Adrees M, Bibi A, Ali S, Nawaz R, Rizwan M (2017) Air pollution tolerance index of plants around brick kilns in Rawalpindi, Pakistan. Journal of environmental management 190:252-258

2. Arnon DI (1949) Copper enzymes in isolated chloroplasts. Polyphenoloxidase in Beta vulgaris. Plant physiology 24(1):1

3. Barceló JUAN, Poschenrieder C (1990) Plant water relations as affected by heavy metal stress: a review. Journal of plant nutrition 13(1):1-37

4. Bhaduri AM, Fulekar MH (2012) Antioxidant enzyme responses of plants to heavy metal stress. Reviews in Environmental Science Bio/Technology 11(1):55-69

5. Bharti SK, Trivedi A, Kumar N (2018) Air pollution tolerance index of plants growing near an industrial site. Urban climate 24:820-829

6. Black Smith Institute Report (2007) The world's worst polluted places. A project of Blacksmith Institute, pp 16-17

7. Castanheiro A, Hofman J, Nuyts G, Joosen S, Spassov S, Blust R, Lenaerts S, De Wael K, Samson R (2020) Leaf accumulation of atmospheric dust: Biomagnetic, morphological and elemental evaluation using SEM, ED-XRF and HR-ICP-MS. Atmos Environ 221:117082

8. Chaudhary IJ, Rathore D (2019) Dust pollution: Its removal and effect on foliage physiology of urban trees. Sustainable Cities Society $51: 101696$

9. Chen YM, Lucas PW, Wellburn AR (1991) Relationship between foliar injury and changes in antioxidant levels in red and Norway spruce exposed to acidic mists. Environ Pollut 69(1):1-15

10. Christou A, Georgiadou EC, Zissimos AM, Christoforou IC, Christofi C, Neocleous D, Dalias P, Torrado SO, Argyraki A, Fotopoulos V (2020) Hexavalent chromium leads to differential hormetic or damaging effects in alfalfa (Medicago sativa L.) plants in a concentrationdependent manner by regulating nitro-oxidative and proline metabolism. Environ Pollut 267:115379

11. Das PK, Das BP, Dash P (2020) Chromite mining pollution, environmental impact, toxicity and phytoremediation: a review. Environmental Chemistry Letters, 1-13

12. Das PK, Das BP, Dash P (2020) Chromite mining pollution, environmental impact, toxicity and phytoremediation: a review. Environmental Chemistry Letters, 1-13

13. DesMarias TL, Costa M (2019) Mechanisms of chromium-induced toxicity. Current opinion in toxicology 14:1-7

14. Dhal B, Das NN, Pandey BD, Thatoi HN (2011) Environmental quality of the Boula-Nuasahi chromite mine area in India. Mine Water Environ 30(3):191-196

15. Escobedo FJ, Wagner JE, Nowak DJ, De la Maza CL, Rodriguez M, Crane DE (2008) Analyzing the cost effectiveness of Santiago, Chile's policy of using urban forests to improve air quality. Journal of environmental management 86(1):148-157

16. Gheorghe IF, Ion B (2011) The effects of air pollutants on vegetation and the role of vegetation in reducing atmospheric pollution. The impact of air pollution on health, economy, environment and agricultural sources, 241-280

17. Golui D, Datta SP, Dwivedi BS, Meena MC, Trivedi VK, Jaggi S, Bandyopadhyay KK (2021) Assessing Geoavailability of Zinc, copper, nickel, lead and cadmium in polluted soils using short sequential extraction scheme. Soil Sediment Contamination: An International Journal 30(1):74-91

18. Gupta GP, Kumar B, Kulshrestha UC (2016) Impact and pollution indices of urban dust on selected plant species for green belt development: mitigation of the air pollution in NCR Delhi, India. Arab J Geosci 9(2):136

19. Hu Y, Wang D, Wei L, Zhang X, Song B (2014) Bioaccumulation of heavy metals in plant leaves from Yan $\square$ an city of the Loess Plateau, China. Ecotoxicol Environ Saf 110:82-88

20. Indian bureau of mines (2013) Monograph on chromite. 1-153

21. Javanmard Z, Kouchaksaraei MT, Hosseini SM, Pandey AK (2020) Assessment of anticipated performance index of some deciduous plant species under dust air pollution. Environ Sci Pollut Res 27(31):38987-38994

22. Jia M, Zhou D, Lu S, Yu J (2021) Assessment of foliar dust particle retention and toxic metal accumulation ability of fifteen roadside tree species: Relationship and mechanism. Atmospheric Pollution Research 12(1):36-45

23. Jones MB (1985) Plant microclimate. In Techniques in bioproductivity and photosynthesis 26-40

24. Karakoti N, Bajpai R, Upreti DK, Mishra GK, Srivastava A, Nayaka S (2014) Effect of metal content on chlorophyll fluorescence and chlorophyll degradation in lichen Pyxine cocoes (Sw.) Nyl.: a case study from Uttar Pradesh, India. Environmental earth sciences 71(5):2177-2183 
25. Karmakar D, Padhy PK (2019) Air pollution tolerance, anticipated performance, and metal accumulation indices of plant species for greenbelt development in urban industrial area. Chemosphere 237:124522

26. Karmakar D, Deb K, Padhy PK (2021) Ecophysiological responses of tree species due to air pollution for biomonitoring of environmental health in urban area. Urban Climate 35:100741

27. Kaur M, Nagpal AK (2017) Evaluation of air pollution tolerance index and anticipated performance index of plants and their application in development of green space along the urban areas. Environ Sci Pollut Res 24(23):18881-18895

28. Keller T (1986) The electrical conductivity of Norway spruce needle diffusate as affected by certain air pollutants. Tree physiology $1(1): 85-94$

29. Khazini L, Dehkharghanian ME, Vaezihir A (2021) Dispersion and modeling discussion of aerosol air pollution caused during mining and processing of open-cast mines. International Journal of Environmental Science and Technology, 1-12

30. Kong SSK, Fu JS, Dong X, Chuang MT, Ooi MCG, Huang WS, Griffith SM, Pani SK, Lin NH (2021) Sensitivity analysis of the dust emission treatment in CMAQv5. 2.1 and its application to long-range transport over East Asia. Atmospheric Environment, $\mathrm{p} 118441$

31. Lèbre É, Corder G, Golev A (2017) The role of the mining industry in a circular economy: a framework for resource management at the mine site level. J Ind Ecol 21(3):662-672

32. Leonard RJ, McArthur C, Hochuli DF (2016) Particulate matter deposition on roadside plants and the importance of leaf trait combinations, 20. Urban Forestry \& Urban Greening, pp 249-253

33. Liu YJ, Ding HUI (2008) Variation in air pollution tolerance index of plants near a steel factory: Implication for landscape-plant species selection for industrial areas. WSEAS Transactions on Environment development 4(1):24-32

34. Manara A (2012) Plant responses to heavy metal toxicity. In: Plants and heavy metals. Springer, Dordrecht, pp 27-53

35. Mo L, Ma Z, Xu Y, Sun F, Lun X, Liu X, Chen J, Yu X (2015) Assessing the capacity of plant species to accumulate particulate matter in Beijing, China. Plos one 10(10):140664

36. Molnár V, Simon E, Tóthmérész B, Ninsawat S, Szabó S (2020) Air pollution induced vegetation stress-the air pollution tolerance index as a quick tool for city health evaluation. Ecol Ind 113:106234

37. Mondal D, Gupta S, Datta JK (2011) Anticipated performance index of some tree species considered for green belt development in an urban area. International Research Journal of Plant Science 2(4):99-106

38. Nadgórska-Socha A, Kandziora-Ciupa M, Trzęsicki M, Barczyk G (2017) Air pollution tolerance index and heavy metal bioaccumulation in selected plant species from urban biotopes. Chemosphere 183:471-482

39. Nayak S, Kale P (2020) A review of chromite mining in Sukinda Valley of India: impact and potential remediation measures. Int $J$ Phytoremediation 22(8):804-818

40. Ni ZZ, Luo K, Zhang JX, Feng R, Zheng HX, Zhu HR, Wang JF, Fan JR, Gao X, Cen KF (2018) Assessment of winter air pollution episodes using long-range transport modeling in Hangzhou, China, during World Internet Conference, 2015. Environmental pollution, 236, 550-561

41. Norouzi S, Khademi H, Cano AF, Acosta JA (2015) Using plane tree leaves for biomonitoring of dust borne heavy metals: a case study from Isfahan, Central Iran. Ecological indicators 57:64-73

42. Oluwoye I, Dlugogorski BZ, Gore J, Oskierski HC, Altarawneh M (2017) Atmospheric emission of NOx from mining explosives: A critical review. Atmos Environ 167:81-96

43. Perl-Treves R, Perl A (2002) Oxidative stress: an introduction. Oxidative stress in plants, 1-32

44. Puckett KJ, Nieboer E, Flora WP, Richardson DHS (1973) Sulphur dioxide: its effect on photo-synthetic 14C fixation in lichens and suggested mechanisms of phytotoxicity. New Phytol 72(1):141-154

45. Rai PK, Panda LL (2014) Dust capturing potential and air pollution tolerance index (APTI) of some road side tree vegetation in Aizawl, Mizoram, India: an Indo-Burma hot spot region. Air Quality Atmosphere Health 7(1):93-101

46. Rai PK (2016) Impacts of particulate matter pollution on plants: Implications for environmental biomonitoring. Ecotoxicol Environ Saf 129:120-136

47. Remon E, Bouchardon JL, Le Guédard M, Bessoule JJ, Conord C, Faure O (2013) Are plants useful as accumulation indicators of metal bioavailability? Environ Pollut 175:1-7

48. Roy A, Bhattacharya T, Kumari M (2020) Air pollution tolerance, metal accumulation and dust capturing capacity of common tropical trees in commercial and industrial sites. Science of The Total Environment 722:137622

49. Safari F, Akramian M, Salehi-Arjmand H, Khadivi A (2019) Physiological and molecular mechanisms underlying salicylic acid-mitigated mercury toxicity in lemon balm (Melissa officinalis L.). Ecotoxicol Environ Saf 183:109542 
50. Sahu C, Basti S (2020) Trace metal pollution in the environment: a review. International Journal of Environmental Science and Technology, 1-14

51. Samecka-Cymerman A, Kempers AJ (1999) Bioindication of heavy metals in the town Wrocław (Poland) with evergreen plants. Atmos Environ 33(3):419-430

52. Selmi W, Weber C, Rivière E, Blond N, Mehdi L, Nowak D (2016) Air pollution removal by trees in public green spaces in Strasbourg city, France, 17. Urban Forestry \& Urban Greening, pp 192-201

53. Serbula SM, Kalinovic TS, Ilic AA, Kalinovic JV, Steharnik MM (2012) Assessment of airborne heavy metal pollution using Pinus spp. and Tilia spp. Aerosol Air Quality Research 13(2):563-573

54. Shahid M, Shamshad S, Rafiq M, Khalid S, Bibi I, Niazi NK, Dumat C, Rashid MI (2017) Chromium speciation, bioavailability, uptake, toxicity and detoxification in soil-plant system: a review. Chemosphere 178:513-533

55. Singh SK, Rao DN, Agrawal M, Pandey J, Naryan D (1991) Air pollution tolerance index of plants. J Environ Manage 32(1):45-55

56. Singh SN, Verma A (2007) Phytoremediation of air pollutants: a review. Environmental bioremediation technologies, pp $293-314$

57. Smirnoff N, Wheeler GL (2000) Ascorbic acid in plants: biosynthesis and function. CRC Crit Rev Plant Sci 19(4):267-290

58. Wang Y, Zhao H, Qin H, Li Z, Liu H, Wang J, Zhang H, Quan R, Huang R, Zhang Z (2018) The synthesis of ascorbic acid in rice roots plays an important role in the salt tolerance of rice by scavenging ROS. Int J Mol Sci 19(11):3347

59. WHO (1996) Denneman and Robberse 1990; Ministry of Housing, Netherlands 1994

60. Xiu Z, Nie W, Yan J, Chen D, Cai P, Liu Q, Du T, Yang B (2020) Numerical simulation study on dust pollution characteristics and optimal dust control air flow rates during coal mine production. J Clean Prod 482:119197

61. Zhang PQ, Liu YJ, Chen X, Yang Z, Zhu MH, Li YP (2016) Pollution resistance assessment of existing landscape plants on Beijing streets based on air pollution tolerance index method. Ecotoxicol Environ Saf 132:212-223

\section{Tables}


Table 1

Assessment of APTI of selected plant species from mining and control area

\begin{tabular}{|c|c|c|c|c|c|c|}
\hline Species & Area & $\begin{array}{l}\text { Total chlorophyll } \\
(\mathrm{mg} / \mathrm{g})\end{array}$ & $\mathrm{pH}$ & Relative water content (\%) & Ascorbic acid (mg/g) & APTI \\
\hline \multirow[t]{2}{*}{ Ailanthus excelsa } & Mining & $0.73 \pm 0.01$ & $5.16 \pm 0.04$ & $64.81 \pm 7.76$ & $10.2 \pm 0.81$ & 12.48 \\
\hline & Control & $1.06 \pm 0.13$ & $6 \pm 0.29$ & $69.31 \pm 1.32$ & $5.56 \pm 0.91$ & 10.85 \\
\hline \multirow[t]{2}{*}{ Bixa orellana } & Mining & $0.44 \pm 0.01$ & $5.1 \pm 0.06$ & $70.90 \pm 1.44$ & $12.33 \pm 2.86$ & 13.92 \\
\hline & Control & $0.75 \pm 0.09$ & $5.53 \pm 0.12$ & $79.62 \pm 1.37$ & $9.32 \pm 0.92$ & 11.82 \\
\hline \multirow[t]{2}{*}{ Callicarpa tomentosa } & Mining & $0.63 \pm 0.006$ & $6.29 \pm 0.11$ & $80.37 \pm 1.64$ & $9.46 \pm 1.93$ & 14.58 \\
\hline & Control & $1.36 \pm 0.19$ & $6.62 \pm 0.16$ & $95.87 \pm 0.75$ & $4.11 \pm 0.7$ & 12.86 \\
\hline \multirow[t]{2}{*}{ Combretum roxburghii } & Mining & $0.61 \pm 0.009$ & $5.42 \pm 0.05$ & $71.3 \pm 0.95$ & $8.76 \pm 0.95$ & 18.71 \\
\hline & Control & $1.03 \pm 0.12$ & $5.85 \pm 0.24$ & $74.71 \pm 1.3$ & $4.72 \pm 1.03$ & 10.71 \\
\hline \multirow[t]{2}{*}{ Ficus hispida } & Mining & $0.82 \pm 0.002$ & $6.8 \pm 0.13$ & $75.63 \pm 1.15$ & $19.53 \pm 2.69$ & 22.52 \\
\hline & Control & $0.9 \pm 0.07$ & $7.17 \pm 0.14$ & $98.22 \pm 0.33$ & $8.89 \pm 0.78$ & 16.99 \\
\hline \multirow[t]{2}{*}{ Holarrhena pubescens } & Mining & $1.81 \pm 0.01$ & $6.13 \pm 0.02$ & $89.38 \pm 2.63$ & $26.83 \pm 1.01$ & 30.24 \\
\hline & Control & $2.33 \pm 0.22$ & $6.97 \pm 0.14$ & $95.63 \pm 1.6$ & $11.36 \pm 2.22$ & 20.12 \\
\hline \multirow[t]{2}{*}{ Macaranga peltata } & Mining & $1.12 \pm 0.05$ & $5.61 \pm 0.03$ & $93.71 \pm 2.69$ & $24.66 \pm 0.1$ & 25.96 \\
\hline & Control & $1.43 \pm 0.24$ & $7 \pm 0.09$ & $94.72 \pm 0.88$ & $14.28 \pm 0.93$ & 21.51 \\
\hline \multirow[t]{2}{*}{ Terminalia arjuna } & Mining & $0.87 \pm 0.006$ & $5.16 \pm 0.09$ & $74.1 \pm 2.13$ & $15.1 \pm 1.61$ & 16.51 \\
\hline & Control & $1.31 \pm 0.2$ & $6.05 \pm 0.17$ & 77.873 .03 & $12.85 \pm 0.57$ & 17.24 \\
\hline \multirow[t]{2}{*}{ Trema orientalis } & Mining & $1.31 \pm 0.11$ & $6.27 \pm 0.03$ & $83.56 \pm 5.06$ & $22.81 \pm 0.8$ & 25.64 \\
\hline & Control & $1.39 \pm 0.19$ & $6.41 \pm 0.04$ & $81.47 \pm 1.36$ & $8.78 \pm 1.07$ & 15 \\
\hline \multirow[t]{2}{*}{ Woodfordia fruticosa } & Mining & $0.59 \pm 0.007$ & $5.41 \pm 0.02$ & $86.16 \pm 2.88$ & $9.86 \pm 1.22$ & 14.52 \\
\hline & Control & $1.16 \pm 0.19$ & $6.32 \pm 0.12$ & $86.12 \pm 4.74$ & $7.01 \pm 0.33$ & 13.85 \\
\hline
\end{tabular}


Table 2

Assessment of API of selected plant species

\begin{tabular}{|c|c|c|c|c|c|c|c|c|c|c|c|}
\hline \multirow[t]{2}{*}{ Species } & \multirow[t]{2}{*}{ APTI } & \multirow{2}{*}{$\begin{array}{l}\text { Plant } \\
\text { habit }\end{array}$} & \multirow{2}{*}{$\begin{array}{l}\text { Canopy } \\
\text { structure }\end{array}$} & \multirow{2}{*}{$\begin{array}{l}\text { Type } \\
\text { of } \\
\text { plant }\end{array}$} & \multicolumn{3}{|c|}{ Laminar } & \multirow{2}{*}{$\begin{array}{l}\text { Economic } \\
\text { importance }\end{array}$} & \multicolumn{2}{|c|}{ Grade allotted } & \multirow[t]{2}{*}{ Assessment } \\
\hline & & & & & Size & Texture & Hardiness & & $\begin{array}{l}\text { Total } \\
\text { plus }\end{array}$ & $\begin{array}{l}\% \\
\text { scoring }\end{array}$ & \\
\hline \multicolumn{12}{|l|}{ Mining } \\
\hline $\begin{array}{l}\text { Ailanthus } \\
\text { excelsa }\end{array}$ & + & + & + & & + & + & & + & 6 & 37.5 & Very poor \\
\hline $\begin{array}{l}\text { Bixa } \\
\text { orellana }\end{array}$ & + & + & + & + & + & & & + & 6 & 37.5 & Very poor \\
\hline $\begin{array}{l}\text { Callicarpa } \\
\text { tomentosa }\end{array}$ & + & + & + & & ++ & + & + & + & 8 & 50 & Poor \\
\hline $\begin{array}{l}\text { Combretum } \\
\text { roxburghii }\end{array}$ & ++ & + & + & + & + & & + & + & 8 & 50 & Poor \\
\hline $\begin{array}{l}\text { Ficus } \\
\text { hispida }\end{array}$ & +++ & + & + & & ++ & + & + & ++ & 11 & 68.75 & Good \\
\hline $\begin{array}{l}\text { Holarrhena } \\
\text { pubescens }\end{array}$ & +++++ & + & + & + & ++ & & & ++ & 12 & 75 & Very good \\
\hline $\begin{array}{l}\text { Macaranga } \\
\text { peltata }\end{array}$ & ++++ & ++ & ++ & + & ++ & + & & + & 13 & 81.25 & Excellent \\
\hline $\begin{array}{l}\text { Terminalia } \\
\text { tomentosa }\end{array}$ & ++ & ++ & ++ & & + & & & ++ & 9 & 56.25 & Moderate \\
\hline $\begin{array}{l}\text { Trema } \\
\text { orientalis }\end{array}$ & ++++ & + & + & + & - & + & & + & 9 & 56.25 & Moderate \\
\hline \multirow[t]{2}{*}{$\begin{array}{l}\text { Woodfordia } \\
\text { fruticosa }\end{array}$} & + & & & + & & + & & + & 4 & 25 & $\begin{array}{l}\text { Not } \\
\text { recommended }\end{array}$ \\
\hline & & & & & \multicolumn{3}{|c|}{ Control } & & & & \\
\hline $\begin{array}{l}\text { Ailanthus } \\
\text { excelsa }\end{array}$ & & + & + & & + & + & & + & 5 & 31.25 & Very poor \\
\hline $\begin{array}{l}\text { Bixa } \\
\text { orellana }\end{array}$ & + & + & + & + & + & & & + & 6 & 37.5 & Very poor \\
\hline $\begin{array}{l}\text { Callicarpa } \\
\text { tomentosa }\end{array}$ & + & + & + & & ++ & + & + & + & 8 & 50 & Poor \\
\hline $\begin{array}{l}\text { Combretum } \\
\text { roxburghii }\end{array}$ & & + & + & + & + & & + & + & 6 & 37.5 & Very poor \\
\hline $\begin{array}{l}\text { Ficus } \\
\text { hispida }\end{array}$ & ++ & + & + & & ++ & + & + & ++ & 10 & 62.5 & Good \\
\hline $\begin{array}{l}\text { Holarrhena } \\
\text { pubescens }\end{array}$ & +++ & + & + & + & ++ & & & ++ & 10 & 62.5 & Good \\
\hline $\begin{array}{l}\text { Macaranga } \\
\text { peltata }\end{array}$ & ++ & ++ & ++ & + & ++ & + & & + & 11 & 68.75 & Good \\
\hline $\begin{array}{l}\text { Terminalia } \\
\text { arjuna }\end{array}$ & ++ & ++ & ++ & & + & & & ++ & 9 & 56.25 & Moderate \\
\hline $\begin{array}{l}\text { Trema } \\
\text { orientalis }\end{array}$ & + & + & + & + & - & + & & + & 6 & 37.5 & Very poor \\
\hline $\begin{array}{l}\text { Woodfordia } \\
\text { fruticosa }\end{array}$ & + & & & + & & + & & + & 4 & 25 & $\begin{array}{l}\text { Not } \\
\text { recommended }\end{array}$ \\
\hline
\end{tabular}


Table 3

DCC of plants $\left(\mathrm{mg} / \mathrm{cm}^{2}\right)$ in mining and control area

\begin{tabular}{|lll|}
\hline Species & Mining & Control \\
\hline Ailanthus excelsa & $1.4 \pm 0.26$ & $0.17 \pm .02$ \\
\hline Bixa orellana & $1.07 \pm 0.19$ & $0.19 \pm 0.1$ \\
\hline Callicarpa tomentosa & $4.26 \pm 0.27$ & $0.37 \pm .07$ \\
\hline Combretum roxburghii & $1.25 \pm 0.30$ & $0.16 \pm 0.14$ \\
\hline Ficus hispida & $5.94 \pm 0.43$ & $0.36 \pm 0.2$ \\
\hline Holarrhena pubescens & $3.61 \pm 0.43$ & $0.23 \pm 0.04$ \\
\hline Macaranga peltata & $3.52 \pm 0.32$ & $0.39 \pm 0.1$ \\
\hline Terminalia arjuna & $2.54 \pm 0.55$ & $0.33 \pm 0.2$ \\
\hline Trema orientalis & $3.55 \pm 0.36$ & $0.28 \pm 0.07$ \\
\hline Woodfordia fruticosa & $1.03 \pm 0.11$ & $0.14 \pm 0.06$ \\
\hline
\end{tabular}


Table 4

Heavy metal in plant leaves $(\mathrm{mg} / \mathrm{kg}$ ) and their respective MAI

\begin{tabular}{|c|c|c|c|c|c|c|c|}
\hline Species & Al & $\mathrm{Cr}$ & $\mathrm{Fe}$ & $\mathrm{Ni}$ & $\mathrm{Pb}$ & $\mathrm{Zn}$ & MAl \\
\hline \multicolumn{8}{|l|}{ Mining } \\
\hline Ailanthus excelsa & $\begin{array}{l}389.76 \pm \\
20.06\end{array}$ & $195.7 \pm 18.74$ & $2570 \pm 188.47$ & $38.06 \pm 2.8$ & $11.17 \pm 1.26$ & $35.6 \pm 2.95$ & 7.46 \\
\hline Bixa orellana & $\begin{array}{l}241.16 \pm \\
36.26\end{array}$ & $52.58 \pm 2.8$ & $3105.33 \pm 374.78$ & $37.83 \pm 6.4$ & $2.06 \pm 0.69$ & $18.86 \pm 1.62$ & 5.17 \\
\hline Callicarpa tomentosa & $\begin{array}{l}239.56 \pm \\
28.35\end{array}$ & $48.96 \pm 2.58$ & $3072 \pm 30.99$ & $19.66 \pm 2.43$ & $1.8 \pm 0.53$ & $18.65 \pm 0.44$ & 17.29 \\
\hline Combretum roxburghii & $430.76 \pm 23.7$ & $151.71 \pm 24.56$ & $3870.3 \pm 695.79$ & $64.56 \pm 7.66$ & $2.03 \pm 0.2$ & $24.23 \pm 2.65$ & 5.52 \\
\hline Ficus hispida & $\begin{array}{l}1358.76 \pm \\
23.7\end{array}$ & $432.26 \pm 24.16$ & $6793.93 \pm 797.15$ & $32.06 \pm 1.21$ & $1.06 \pm 0.07$ & $15.86 \pm 2.25$ & 10.31 \\
\hline Holarrhena pubescens & $\begin{array}{l}404.42 \pm \\
13.47\end{array}$ & $110.4 \pm 5.57$ & $1891.93 \pm 67.55$ & $45.13 \pm 4.22$ & $1.23 \pm 0.26$ & $19.13 \pm 2.37$ & 9.74 \\
\hline Macaranga peltata & $\begin{array}{l}833.06 \pm \\
25.15\end{array}$ & $328.03 \pm 14.1$ & $5239 \pm 253.49$ & $62.56 \pm 4.33$ & $2.76 \pm 0.61$ & $37.93 \pm 3.92$ & 10.16 \\
\hline Terminalia tommentosa & $326.16 \pm 11.2$ & $99.36 \pm 12.26$ & $1677.53 \pm 170.98$ & $33.06 \pm 2.6$ & $6.8 \pm 0.79$ & $30.06 \pm 6.03$ & 7.05 \\
\hline Trema orientalis & $183.2 \pm 10.42$ & $72.23 \pm 6.37$ & $1028.86 \pm 5569$ & $19.26 \pm 1.85$ & $3.13 \pm 0.9$ & $20.93 \pm 2.01$ & 6.89 \\
\hline Woodfordia fruticosa & $\begin{array}{l}159.43 \pm \\
14.29\end{array}$ & $162.13 \pm 31.5$ & $2138.16 \pm 232.16$ & $27.5 \pm 3.01$ & $2.18 \pm 0.32$ & $17.2 \pm 1.62$ & 4.99 \\
\hline \multicolumn{8}{|l|}{ Control } \\
\hline Ailanthus excelsa & $1.44 \pm 0.33$ & $1.85 \pm 0.19$ & $74 \pm 21.41$ & $1.82 \pm 0.38$ & $0.24 \pm 0.07$ & $4.23 \pm 1.05$ & 2.82 \\
\hline Bixa orellana & $2.37 \pm 0.67$ & $1.29 \pm 0.32$ & $193.33 \pm 54.07$ & $2.11 \pm 0.8$ & $0.05 \pm 0.01$ & $3.58 \pm 1.37$ & 1.94 \\
\hline Callicarpa tomentosa & $2.52 \pm 0.48$ & $1.69 \pm 0.41$ & $245.89 \pm 36.75$ & $1.09 \pm 0.25$ & $0.06 \pm 0.01$ & $4.95 \pm 1.27$ & 2.88 \\
\hline Combretum roxburghii & $4.43 \pm 0.72$ & $2.56 \pm 0.45$ & $184 \pm 43.18$ & $1.3 \pm 0.8$ & $0.07 \pm 0.006$ & $0.94 \pm 0.2$ & 3.4 \\
\hline Ficus hispida & $5.23 \pm 1.36$ & $3.1 \pm 0.08$ & $240.9 \pm 26.78$ & $1.88 \pm 0.22$ & $0.05 \pm 0.009$ & $2.07 \pm 0.82$ & 6.38 \\
\hline Holarrhena pubescens & $0.89 \pm 0.22$ & $2.01 \pm 0.46$ & $61.55 \pm 7.94$ & $2.51 \pm 0.43$ & 0 & $2.01 \pm 0.82$ & 2.34 \\
\hline Macaranga peltata & $1.69 \pm 0.53$ & $1.49 \pm 0.26$ & $215.11 \pm 3146$ & $2.03 \pm 0.51$ & $0.08 \pm 0.009$ & $5.2 \pm 1.22$ & 3.15 \\
\hline Terminalia tommentosa & $0.76 \pm 0.17$ & $1.76 \pm 0.15$ & $117.47 \pm 18.9$ & $1.39 \pm 0.42$ & $0.12 \pm 0.02$ & $5.85 \pm 1.75$ & 3.17 \\
\hline Trema orientalis & $0.62 \pm 0.28$ & $0.53 \pm 0.26$ & $57.03 \pm 15.18$ & $1.03 \pm 0.23$ & $0.07 \pm 0.02$ & $2.46 \pm 0.32$ & 2.26 \\
\hline Woodfordia fruticosa & $0.91 \pm 0.3$ & $1.35 \pm 0.16$ & $121.96 \pm 28.66$ & $1.6 \pm 0.26$ & $0.43 \pm 0.01$ & $3.37 \pm 1.16$ & 2.57 \\
\hline
\end{tabular}

\section{Figures}


a.

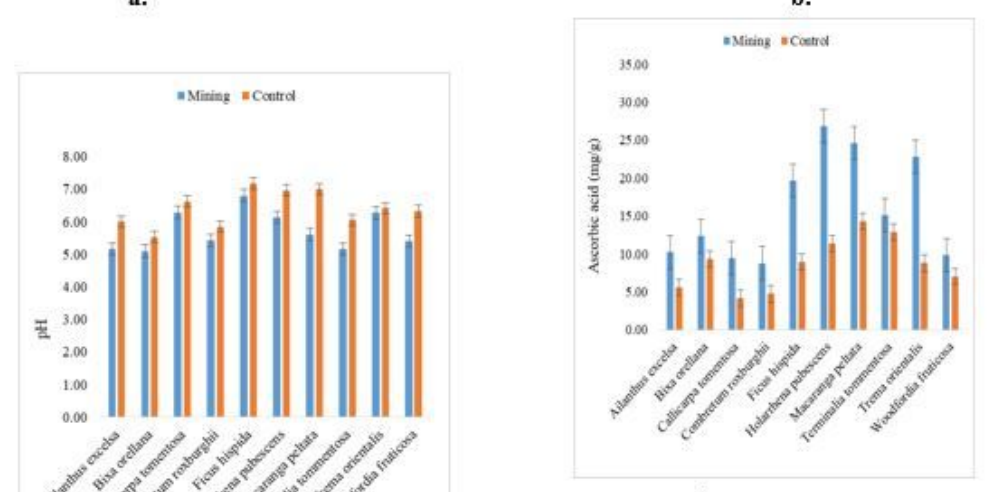

d.

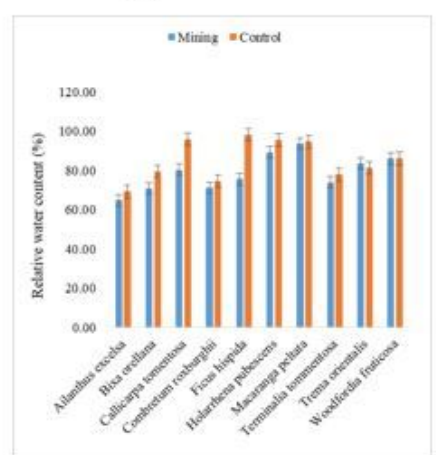

e.

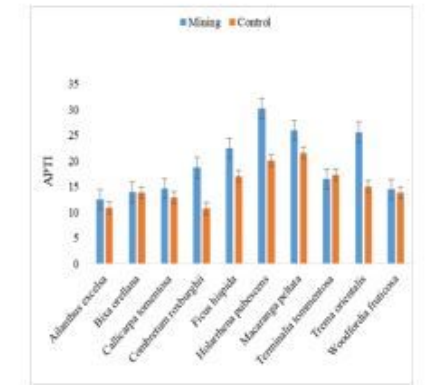

Figure 1

Area wise difference in a. pH, b. Ascorbic acid, c. total chlorophyll content, d. relative water content, and e. APTI of selected plant. Error bars refer to standard error 